\title{
Ammatillinen aikuiskoulutus ja aikuiskouluttajakoulutus
}

\author{
Tässä artikkelissa käsitellään ajankohtaista ammatillista \\ aikuiskoulutusta ja siihen liittyvää aikuiskouluttajakoulutusta. \\ Edessä on mittava aikuiskoulutustehtävä, mutta onko siihen \\ kouluttajia? Mikä olisi hyvä tapa hoitaa ammatillisen \\ aikuiskouluttajan koulutus? Miten se kytkeytyy muuhun \\ ammatilliseen koulutukseen ja opettajankoulutukseen sekä \\ toisaalta yleissivistävään aikuiskoulutukseen? Miten uudet \\ monimuoto-opetuksen järjestelyt ja tiedonvälityksen \\ mahdollisuudet voisivat auttaa asiassa?
}

Artikkelissa esitellään Ammatillisessa opettajakorkeakoulussa Hämeenlinnassa järjestettyjä ammatilliseen aikuiskoulutukseen ja aikuiskouluttajakoulutukseen liittyviä kokeiluja.

On sanottu, että 1990-luku on aikuiskoulutuksen vuosikymmen. Aikuiskoulutuksen nousuun tärkeäksi koulutuspoliittiseksi tekijäksi on monta syytä. Ammatillisen aikuiskoulutuksen kehittämistä ovat pohtineet useat työryhmät ja toimikunnat. Merkittävä taitekohta oli Valtioneuvoston ammatillista aikuiskoulutusta koskeva periaatepäätös vuonna 1988. Sen jälkeen on ammatillisissa oppilaitoksissa ja ammatillisissa kurssikeskuk. sissa ryhdytty käytännön toimenpiteisiin $\mathrm{mm}$. perustamalla aikuiskoulutusosastoja.

Ammatillista aikuiskoulutusta ovat jo pitkään antaneet ammatilliset kurssikeskukset, joiden opettajilta on vaadittu ao. alan amma. tillisen oppilaitoksen opettajan kelpoisuus. Käytännössä epäpätevien määrä on ollut varsin suuri. Lisäksi ammatillisia aikuiskouluttajia on työelämässä ja sen koulutusorga. nisaatioissa.

Vasta aivan viime vuosina on ryhdytty selvittämään aikuiskouluttajatarvetta ja -koulutusta. Yleissivistävässä aikuiskoulutuksessa opettajankoulutusta on ollut mm. kansan-, kansalais- ja työväenopistojen opettajille, joille on järjestetty pedagogista koulutusta, joka tosin on ollut suhteellisen pienimuotoista.

\section{Ammatillinen aikuiskoulutus ajankohtaista}

Ammatillisella aikuiskoulutuksella on edessään mittava koulutustehtävä. Tarvitaan aikuisväestölle tarkoitettua peruskoulutusta, siihen kytkeytyvää täydennyskoulutusta ja myös uudelleenkoulutusta.

Vielä vuonna 1995 vallitsee sellainen tilanne, että ikäryhmässä 40 vuodesta ylöspäin ammatillinen peruskoulutus puuttuu yli puolelta työssä olevilta (komitean mietintö 1988:28). Tämä merkitsee koulutukselle monenlaista eriyttämisen ja yksilöllistämisen vaatimusta. Kun lisäksi ammatit ja työelämä uudistuvat nyt erityisen voimakkaasti uuden tekniikan vuoksi, on koulutuksen oltava ajanmukaista ja käytännön läheistä. Tuotan- 
non uudelleenorganisointi ja siitä johtuvat työn sisältöjen muutokset vaikuttavat ammattitaidon perusteisiin.

Ammatillisessa opettajakorkeakoulussa Hämeenlinnassa on ollut käynnissä jo muutaman vuoden ajan "Työ ja ammattitaito" -projekti, jossa on arvioitu erilaisten kehitystrendien perusteella ammattitaidon muutosta (Helakorpi ym, 1988). Ammatillisten tietojen ja taitojen ohella näyttäisi ammattitaidoissa korostuvan kolmas komponentti, työn sosiaalisuus. Uludet työn organisaatiomuodot, ovat nostaneet yhteistyötaidot tärkeäksi ammattitaidon osatekijäksi.

Ammatillisen oppilaitoksen opettajalta vaaditaan ennen opettajankoulutukseen pääsyä yleensä vähintään ammatillisella korkea-asteella suoritettu tutkinto ja kolmen vuoden työkokemus. Ammatillinen oppilaitoksen opettajan ammattitaidon elementtejä voitaisiin kuvata seuraavasti (kuva 1):

Substanssin hallinnan ohella ammatillisen aikuiskouluttajan tulee olla pedagogisesti taitava. Ulusi tiedon käsitys ja oppimisnäkemyksen kehittyminen ovat muuttaneet opettajan toimenkuvaa ja asettaneet opettajankoulutukselle uudistumisvaateita. Ammatillinen opettajankoulutus onkin ollut koko 80-luvun voimakkaassa muutosprosessissa. Useiden eri työryhmien työn ja kehittämiskokeilujen tuloksena nyt ollaan siinä tilanteessa, että kaikissa ammatillisiin oppilaitoksiin opettajia kouluttavissa opettajankoulutuslaitoksissa on yhtenäinen 40 opintoviikon pedagoginen opettajankoulutus, joka on vertailukelpoinen yleissivistävän puolen aineenopettajakoulutukseen.

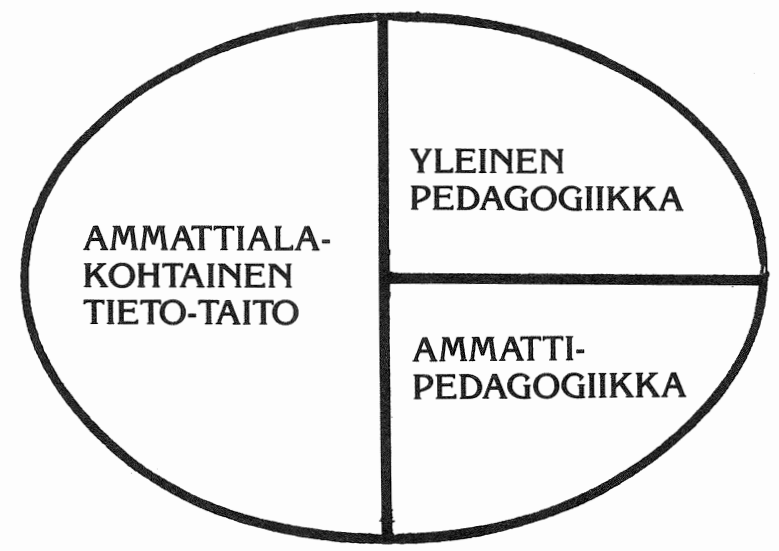

Kuva 1. Ammatillisen oppilaitoksen opettajan ammattitaidon osa-alueet.

\section{Aikuiskoulutuskokeiluja Hämeenlinnassa}

Ammatillinen aikuiskoulutus, siihen kytkeytyvä pedagogiikka ja aikuiskouluttajakoulutus ovat olleet jo useamman vuoden ajan kehittämisen kohteena Ammatillisessa opettajakorkeakoulussa Hämeenlinnassa.

Vuonna 1987 päätimme lähteä kehittämään omaa opettajankoulutusta teemalla "aikuisnäkökulma". Se tarkoitti sitä, että kehitimme omaa pedagogiikkaa ja käytäntöjä ottamaan paremmin huomioon aikuiset opettajakokelaat. Heidän keski-ikänsä on yli 30 vuotta. Tässä aikuiskoulutuskokeilun nimellä kulkevassa kokeiluprojektissa pyritään itseohjautuvaan oppimiseen. Siinä opettajakokelas toimii mahdollisimman paljon itsenäisesti käyttäen hyväksi opettajakorkeakoulussa olevaa tietotaitoa, välineistöä, tiloja ja materiaaleja. Tavoitteena on myös vaikuttaa opiskelumotivaatioon ja toiminnan mielek. kyyteen. Lukuvuonna 1989-90 kokeilu jakaantui neljään osaprojektiin, jotka olivat seuraavat:

1. Teollisuuden ammattioppilaitosten opettajien koulutuksen kokeilu

2. Kognitivisen empatian kokeilu (opettajakokelaat)

3. Monimuoto-opetuskokeilu (ohjaavat opettajat)

4. Syventävän jakson kokeilu (opettajakokelaat).

Näissä osakokeiluissa päätavoiteena on ollut aikuisopiskelussa käytettävissä olevien pedagogisten menetelmien kokeilu. Tarkoituksena on ollut käyttää hyväksi kaikkia niitä etäopiskelun muotoja, joihin uusi tekniikka, tietokoneet ja niiden verkot, videoyhteydet, telefaxit, audiopuhelimet jne. antavat mah. dollisuuksia. 
Kokeilussa ei luonnollisestikaan unohdettu tavanomaisia aikuiskoulutusmenetelmiä eli mukana on myös ongelmakeskeistä yksilöllistä opiskelua, ryhmätyöskentelyä, projektiopiskelua jne. Erityisenä mielenkiinnon kohteena on ollut kognitiivisen empatian kokeilu, jossa pyritään paneutumaan kykyyn ymmärtää empaattisesti oppilasta.

Kokeilun keskeinen anti tulee siis koskemaan aikuiskoulutuksen metodiikkaa; siis millaisia menetelmiä tänä päivänä on käytettävissä monimuoto-opiskelussa ja miten ne soveltuvat aikuisten koulutukseen. Kutakin osaprojektia on selvitetty laajemmin Hi teach -lehdessä 1/1990. Raportti kokeilusta valmistuu syksyn 1990 kuluessa ja julkaistaan opettajakorkeakoulun julkaisusarjassa.

Toinen juuri keväällä alkanut kokeilu koskee aikuiskouluttajakoulutusta. Tämä projekti on edennyt rinnan erilaisten työryhmätöiden edistymisen myötä. Opetusministeriön aikuiskoulutusneuvoston asettaman aikuiskouluttajajaoston raportti valmistui alkuvuodesta 1989 (Opetusministeriö, 1989). Parasta aikaa toimii myös ammattikasvatus. hallituksessa ammatillisen aikuiskouluttajan koulutusta pohtiva työryhmä.

Käsite ammatillinen aikuiskouluttaja on vielä epämääräinen tai ainakin se voidaan käsittää eri tavoin. Ammatillisia aikuiskouluttajia on päätoimisia ja sivutoimisia. He toimivat joko yrityksissä koulutuspäällikköinä, kouluttajina, työnopastajina ja teollisuusoppilaitosten opettajina, tai ammatillisten kurssikeskusten ja ammatillisten oppilaitosten aikuiskoulutusosastojen opettajina. Tähän asti koulutus on ollut sama kuin ammatillisten oppilaitosten opettajille niin, että aikuiskouluttajat ovat opiskelleet samoissa ryhmissä nuorisoasteelle suuntautuvien kokelaiden kanssa. Poikkeuksen ovat muodostaneet teollisuuden ammattioppilaitosten opettajat, joille on järjestetty aivan erityisesti näiden koulumuotojen tarvitsemaa opettajankoulutusta.

Kun tavoitteena on, että tulevaisuudessa ammatillisia opettajia voidaan joustavasti käyttää eri koulumuodoissa tarpeen mukaisesti, herää kysymys, onko tarvetta ja perusteltua muuttaa koulutusta niin, että ammatilliseen aikuiskoulutukseen olisi eriytynyt opettajankoulutus?

Vallitseva käsitys ammatillisen opettajankoulutuslaitosten piirissä on, että erillistä koulutusta ei ole syytä järjestää, vaan yksi ja sama koulutus antaisi valmiuden sekä nuorisoasteelle että ammatilliseen aikuiskoulutukseen. Tällöin nykyistä opettajankoulutusohjelmaa on syytä tarkistaa aikuiskoulutuksen suuntaan (vrt. edellinen kokeiluselostus). Aiemmin valmistuneet, etupäässä nuorisoasteen ammattikoulutukseen valmistuneet opettajat, tarvitsevat kyllä täydennyskoulutusta aikuiskoulutukseen.

Suuri yksimielisyys vallitsee siitä, että työelämässä olevat aikuiskouluttajat tarvitsevat oman erillisen koulutusohjelmansa. Näin monestakin syystä. Ensinnäkin on epärealistista ajatella, että työelämä lähtisi mukaan 40 opintoviikon mittaiseen koulutusohjelmaan, vaikka se olisikin suurelta osin etäopiskelua ja perustuisi työn ohessa tapahtuvaan monimuoto-opiskeluun. Lisäksi koulutustarve vaihtelee eri aloilla ja eri tilanteissa. Koulutuspäällikkö tarvitsee enemmän opetuksen suunnitteluvalmiuksia kuin esimerkiksi työnopastaja, jonka koulutuksessa tulisi painottua opiskelun ohjaamisen sisällöt.

Edellisen perusteella Ammatillisessa opettajakorkeakoulussa Hämeenlinnassa on kokeilua varten kehitetty kolme erilaista koulutusohjelmaa työelämän aikuiskouluttajille ja niille aiemmin valmistuneille ammatillisten oppilaitosten opettajille, jotka tarvitsevat täydennystä aikuispedagogiikassa. Ohjelmat ovat seuraavat:

1. Päätoimisten aikuiskouluttajien koulutusohjelma, laajuus 20 opintoviikkoa

2. Sivutoimisten aikuiskouluttajien koulutusohjelma, laajuus 10 opintoviikkoa

3. Aikuiskouluttajan täydennysjakso opettajille, laajuus 6 opintoviikkoa.

Päätoimisten kouluttajien ohjelma käsittää neljä opintokokonaisuutta: yleispedagogiset opinnot (10 opintoviikkoa, approbaturtaso), ammattipedagogiset opinnot (seitsemän opintoviikkoa), koulutushallinnon, suunnittelun ja pedagogisen johtamisen kurssi (kolme opintoviikkoa) ja opetusharjoittelun, jonka yhteydessä valmistuu myös seminaarityö. Sivutoimisen aikuiskouluttajan 10 opintoviikon ohjelma on muutoin sama, mutta ei käsitä yleispedagogisia opintoja (sisällöt korvataan lyhyellä johdantomateriaalilla ja alkukuulustelulla). Opettajien kuuden opintoviikon aikuiskouluttajan täydennyskoulutusjakso vastaa sivutoimisen aikuiskouluttajan ohjelmaa paitsi, että siitä on karsittu ne osiot, jotka jo ovat sisältyneet aiempaan opettajankoulutukseen. Työelämän ammatillisten aikuiskouluttajien koulutusohjelmia kuvaa oheinen piirros (kuva 2). 


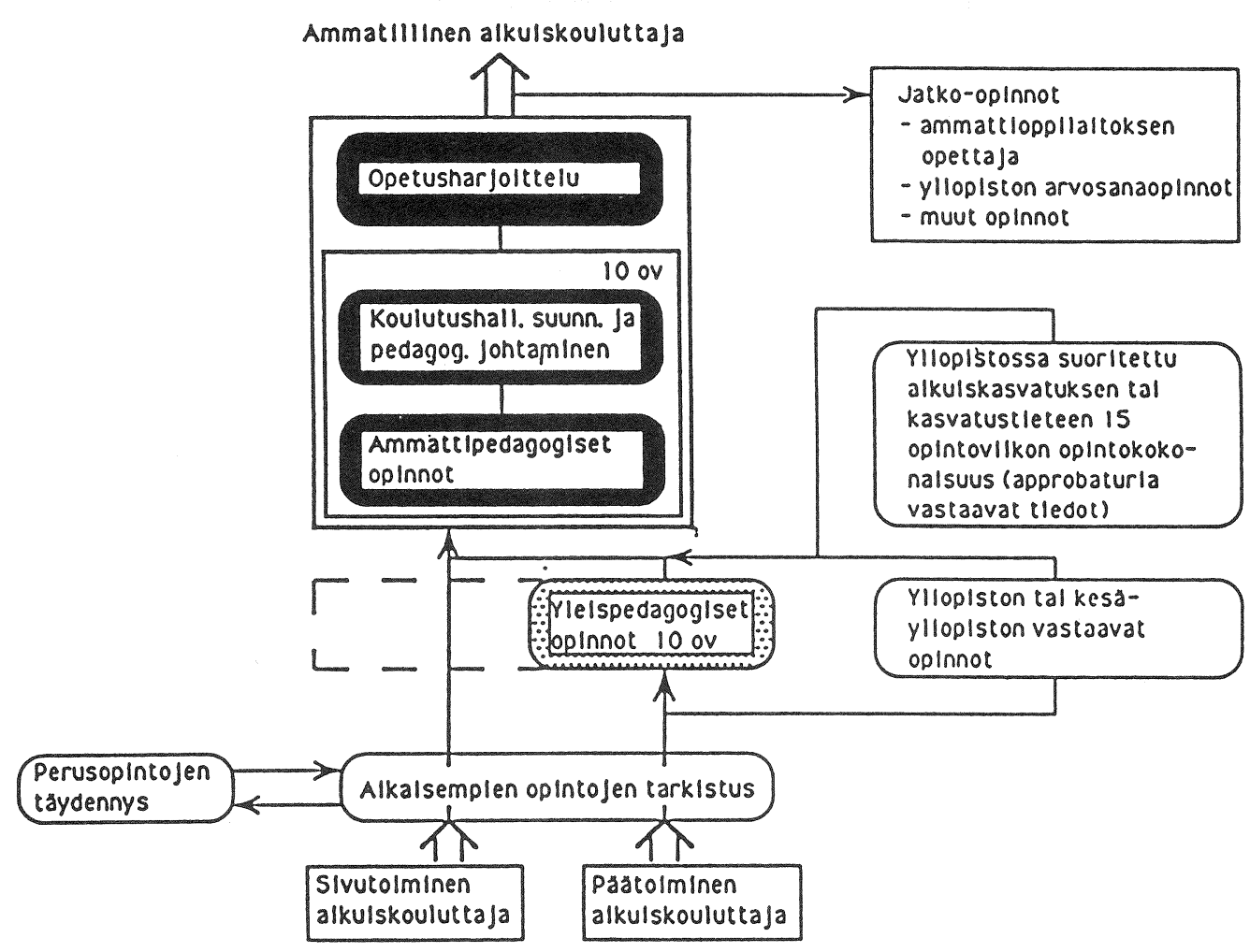

Kuva 2. Ammatillisen aikuiskouluttajan koulutuksen opinto-ohjelmat.

Aikuiskouluttajakoulutuksen kokeilussa koulutus perustuu monimuoto-opetukseen ja opinnot suoritetaan työn ohessa. Etäopis. kelun lisäksi koulutukseen sisältyy muuta. man päivän kontaktiopetusjaksoja. Koko opiskelusta muodostuu tietty projekti, jossa opiskelu kytketään kouluttajan jokapäiväisiin tarpeisiin. Koulutuksessa pyritään antamaan opiskelijoille sellainen koulutuksen toteutusmalli, jota he voivat käyttää myös omassa koulutustehtävässään. Koulutuksen sisällöt on nivelletty myös ammatillista opettajan. koulutusta ajatellen niin, että opinnot voidaan koko osuudeltaan lukea hyväksi mahdollisessa opettajankoulutuksessa. Kokeilun aikana pyritään luomaan myös hyvät yhtey. det yliopistojen arvosanaopintoihin, jotta tarvittaessa opiskelija voi jatkaa aikuisopintoja myös yliopistossa ja sen täydennyskoulutuk. sessa.

Kaiken kaikkiaan olisi tärkeää rakentaa kuiskouluttajakoulutukseen niin, että opiskelijat voisivat myös tässä suunnassa joustavasti siirtyä opettajaksi koulumuodosta toiseen.

\section{LÄHTEET}

Helakorpi S. ym 1988. Työ ja ammattitaito - Work and occupational skill. Ammattikoulujen Hämeenlinnan opettajaopisto, tutkimuksia n:o 5.

Komiteamietintö 1988:28. Väestön koulutus 2000. Koulutussuunnittelun neuvottelutoimikunnan mietintö.

Opetusministeriö 1989. Aikuiskouluttajajaoston raportti. Aikuiskoulutusneuvoston julkaisuja 4/1989. Helsinki

Valtioneuvoston periaatepäätös ammatillisen aikuiskoulutuksen kehittämisestä 24.3.1988. 